\title{
The Characteristics and Predicted of Glycemic Index of Rice Analogue from Modified Arrowroot Starch (Maranta arundinaceae L.)
}

\author{
Damat Damat ${ }^{1, *}$, Roy Hendroko Setyobudi ${ }^{2}$, Joko Susilo Utomo ${ }^{3}$, Zane Vincēviča- \\ Gaile $^{4}$, Anas Tain ${ }^{1}$ and Devi Dwi Siskawardani ${ }^{1}$ \\ ${ }^{1}$ Department of Food Technology, Faculty of Agriculture and Animal Science, University of Muhammadiyah Malang, Jl. Raya Tlogomas No \\ 246, Malang 65144, East Java, Indonesia; ${ }^{2}$ Department of Agriculture Science, Postgraduate Program, University of Muhammadiyah \\ Malang, East Java Indonesia ${ }^{3}$ Indonesian Legumes and Tuber Crops Research Institute, Jl. Raya Kendalpayak No.66, Malang 65162, East \\ Java, Indonesia; ${ }^{4}$ Department of Environmental Science, University of Latvia, Jelgavas Street 1, Room 302, Riga LV-1004, Latvia
}

Received: Feb 20, 2021; Revised: May 28, 2021; Accepted May 29, 2021

\begin{abstract}
The modification of arrowroot starch is able to increase its resistant starch (RS) levels, as the result improve the functional characteristic of rice analogue for healthy diabetics. Therefore, the purpose was to determine the physical characteristics, digestibility, hydrolysis index (HI) and predicted glycemic index (PGI) of rice analogue obtained from modified arrowroot starch. The completely randomized design using single factor was conducted. The proportions of the modified arrowroot starches used were $0 \%, 25 \%, 50 \%, 75 \%$, and $100 \%$. The procedure consisted of formulation, extrusion, and analysis parameter. According to the results, the proportions of the modified arrowroot starch had a significant effect on the microscopy as well as the rice analogue digestibility. The amount of rice analogue obtained from the $100 \%$ modified arrowroot starch was $649 \mu \mathrm{m}$, which was the highest, the digestibility value at 180 min was $14.23 \% \pm 0.17 \%$, HI values at $32.14 \pm 0.20$ and PGI $56.79 \pm 0.14$, which was the smallest when compared with other treatments. It can be concluded that higher proportions of the modified arrowroot starch, resulted in higher grain size, but lower digestibility, hydrolysis index and predicted glycemic index of gluten-free rice analogue.
\end{abstract}

Keywords: Digestibility, Food diversification, Functional rice, Gluten-free rice, Healthy diabetics, Hydrolysis Index

\section{Introduction}

Arrowroot (Maranta arundinaceae L.) is a type of tuber, which is cultivated in some areas in Indonesia (Deswina and Priadi, 2020; Sholichah et al., 2019). Carbohydrate is the main component of this plant and various studies have been conducted to examine its starch constituents (Charles et al., 2016; Damat et al., 2017; Villas-Boas and Franco, 2016). However, the focus of this research was generally on the physical and chemical characteristics of arrowroot starch. Also, research has been conducted on the modification of arrowroot starch through esterification (Damat et al., 2008), cross-linking (Maulani et al., 2013), acetylation (Abba et al., 2014), gelatinization-retrogradation (Damat et al., 2019b; Pepe et al., 2015) as well as through physical modification methods (Astuti et al., 2018).

In addition, the previous research was conducted to the application of arrowroot starch as raw material of rice analogue (Damat et al., 2019b). However, there was not research on the modification of arrowroot starch through gelatinization-retrogradation and its application for functional rice analogue. Moreover, there was not research on the digestibility and predictions of the glycemic index of functional rice analogue obtained modified arrowroot starch.

According to Damat et al. (2019a), the modification of arrowroot starch through gelatinization-retrogradation increased its resistant starch (RS) levels. Consequently, the rice analogue resulting was rich in RS and low in GI. Damat et al. (2008); Damat et al. (2020) reported the importance of food products, which are rich in RS in controlling blood glucose since they had slower digestion rates. Control of blood glucose level was one goal of a healthy diet plan for diabetes sufferers (Al-Jamal and Alqadi, 2011; Bhaskar and Ajay, 2009); therefore, the rice analogues were usually consumed (Budijanto and Yuliana, 2015; Wahjuningsih et al., 2018). The metabolism of RS occurred $5 \mathrm{~h}$ to $7 \mathrm{~h}$ after eating (Lestari et al., 2017); hence, it had the ability to reduce the postprandial glucose levels (Setyobudi et al., 2019). This research aimed to evaluate the microscopic physical properties, in vitro digestibility, hydrolysis index (HI) and the predicted glycemic index (PGI) of the functional rice analogue from modified arrowroot starch.

\section{Materials and Methods}

The arrowroot starch was obtained from the farmers in Malang Regency, East Java. This research was

\footnotetext{
*Corresponding author e-mail: damatumm@gmail.com
} 
conducted in two stages, i) the production of the modified arrowroot starch through gelatinizationretrogradation method (Damat et al., 2018) and ii) the production of the rice analogue. The Completely Randomized Design (CRD), with one factor, which included K0 (Control), K1 (100 \% Natural Arrowroot Starch); K2 (75 \% Natural Arrowroot Starch: $25 \%$ Modified Arrowroot Starch); K3 (50 \% Natural Arrowroot Starch: 50 \% Modified Arrowroot Starch); K4 (25\% Natural Arrowroot Starch: $75 \%$ Modified Arrowroot Starch); and K5 (100 \% Modified Arrowroot Starch) were applied. The result expected was to increase the resistant starch, followed to reduce the degree of hydrolysis and predict the glycemic index of rice analogue.

\subsection{Formulation}

The ingredient formulation consisted of cornstarch, modified cassava flour, natural arrowroot starch, modified arrowroot starch, and water. Moreover, GMS (glycerol monostearate) as an emulsifier was added. The exact formula is presented in Table 1.

Table 1. Formula of rice analogue

\begin{tabular}{lllllll}
\hline Raw material & Ko & K1 & K2 & K3 & K4 & K5 \\
\hline Cornstarch (g) & 250 & 0 & 0 & 0 & 0 & 0 \\
$\begin{array}{l}\text { Modified cassava } \\
\text { flour (g) }\end{array}$ & 250 & 0 & 0 & 0 & 0 & 0 \\
$\begin{array}{l}\text { Natural arrowroot } \\
\text { starch (g) }\end{array}$ & 0 & 500 & 375 & 250 & 125 & 0 \\
$\begin{array}{l}\text { Modified } \\
\text { arrowroot starch }\end{array}$ & 0 & 0 & 125 & 250 & 375 & 500 \\
$\begin{array}{l}\text { (g) } \\
\text { Water (mL) }\end{array}$ & 110 & 110 & 110 & 110 & 110 & 110 \\
$\begin{array}{l}\text { Emulsifier: GMS } \\
\text { (g) }\end{array}$ & 5 & 5 & 5 & 5 & 5 & 5 \\
\hline
\end{tabular}

\subsection{Extrusion}

The ingredients were mixed and steamed for $30 \mathrm{~min}$ at $80^{\circ} \mathrm{C}$. The steamed materials were directly inserted into an extruder in order to form the analogue rice. After analogue, rice granules were formed; they were dried in a dryer cabinet at $50{ }^{\circ} \mathrm{C}$ for $20 \mathrm{~h}$.

Then, analyses of the microscopic properties of the rice analogue was carried out using the modified version of Scanning Electron Microscope by Han et al. (2018), the resistant starch levels (Fabbri et al., 2016), and those of the digestibility, hydrolysis index (HI) and predicted glycemic index (PGI) conducted in vitro in accordance to Ratnaningsih et al. (2017). The research data were expressed as mean \pm deviation standards in triplicate independent analyzes. One-way ANOVA was conducted on the data using SPSS version 17.

\section{Results and Discussion}

Arrowroot starch with different granule morphology were scanned used SEM (Figure 1). Unmodified arrowroot starch resulted round to elliptical granules with a size $9 \mu \mathrm{m}$ to $36 \mu \mathrm{m}$. The starch granules had a smooth surface, and it was consistent with the granular shape of arrowroot starch reported by Charles et al. (2016). While, in the modified arrowroot starch granules showed different, it had a rough and irregular surface (Figure 1).

Modified arrowroot starch granules had a size of $88 \mu \mathrm{m}$ to $591 \mu \mathrm{m}$, which is larger than natural arrowroot starch. Majzoobi et al. (2016) suggested that the increase in grain size might be related to the absorption of acid, causing some internal transformation in the granules. The alteration in the size of starch granules can cause starch digestibility and increase resistant starch level (Damat et al., 2019b). Modification of starch through gelatinizationretrogradation accompanied by cooling changed in the surface of the starch grains becomes uneven. Starch retrogradation generate the granules are difficult to swell and strengthen the grains, to be more heat and shear resistant leading to a lower viscosity. Changes in the structure, size and shape of starch grains induced alteration in the regularity structure of short distances, viscosity, solubility and swelling (Lin et al., 2015).
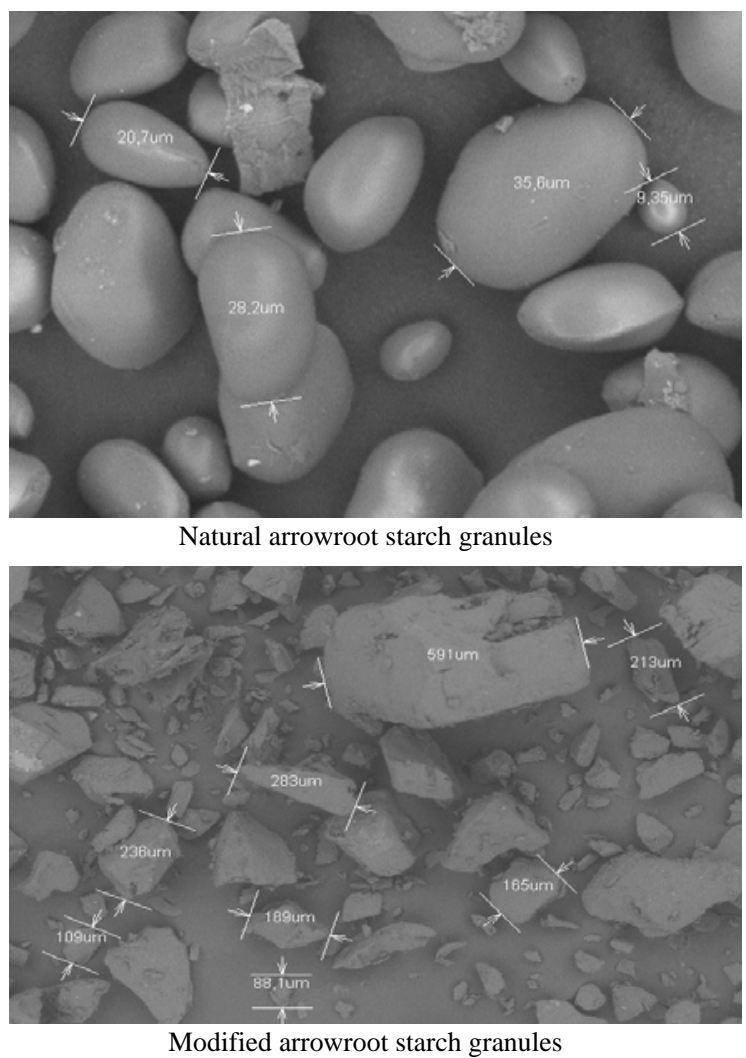

Figure 1. Granules of natural arrowroot starch and modified arrowroot starch

The sizes and the shapes of starch granule rice analogue produced were shown in Figure 2. The K1 treatment (100 $\%$ natural arrowroot starch) was almost the same as $\mathrm{K} 0$, with the size was smaller ranging f r o m 136 $\mu \mathrm{m}$ to $229 \mu \mathrm{m}$. Furthemore, enhancement of modified arrowroot starch induced more irregular and larger size of rice analogue granule. This was due to the incorporation of amylose in the cooling process to form crystals, which different to natural starch. The granule size of rice analogue ranged from $175 \mu \mathrm{m}$ to $649 \mu \mathrm{m}$, with the biggest size ranging from $334 \mu \mathrm{m}$ to $649 \mu \mathrm{m}$, found in the $\mathrm{K} 5$ treatment (100\% modified arrowroot starch). 


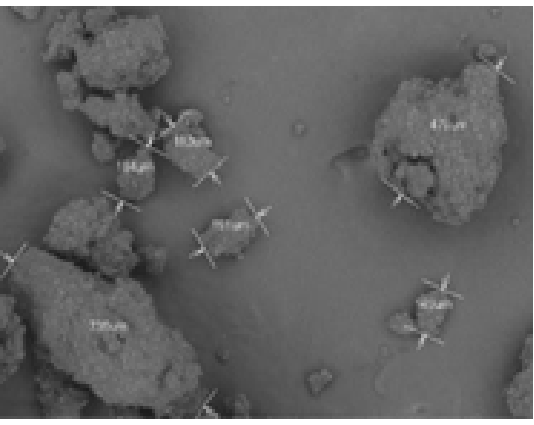

a) K0 starch granule rice analogue

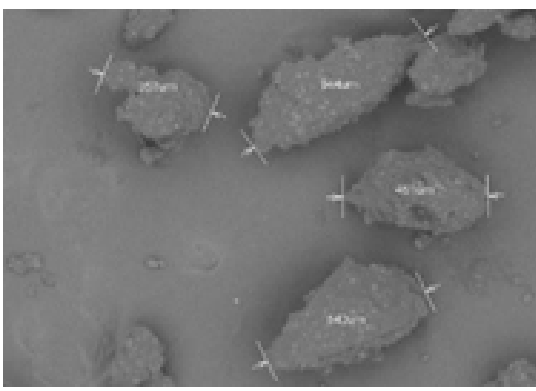

d) K3 starch granule rice analogue

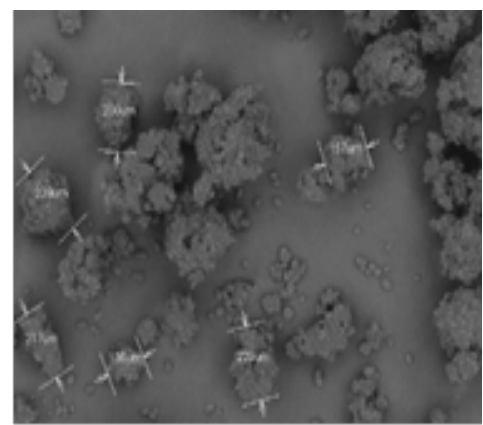

b) K1 starch granule rice analogue

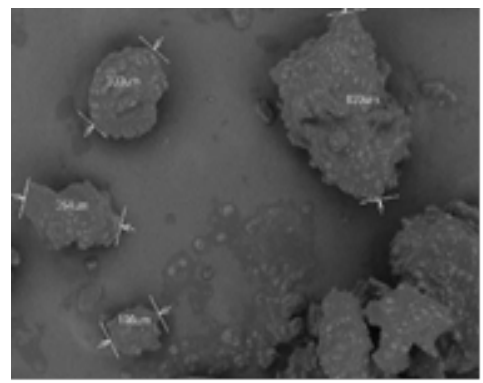

e) K4 starch granule rice analogue

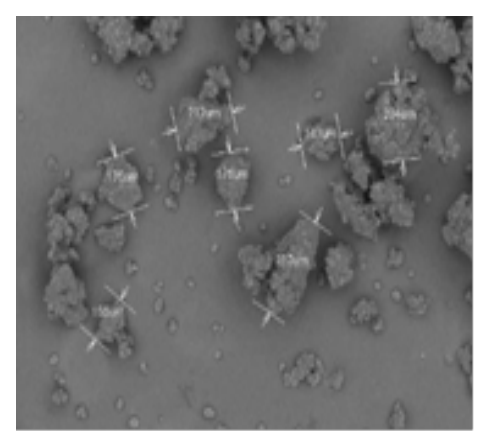

c) K2 starch granule rice analogue

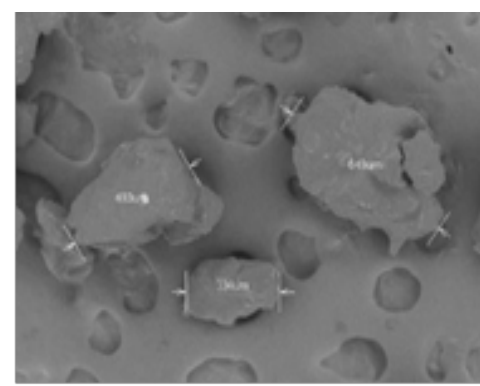

f) K5 starch granule rice analogue

Figure 2. Starch Granule Rice analogue under the Scanning Electron Microscope (SEM) at $100 \times$ magnification

The highest starch resistant rice analogue was found in the treatment $\mathrm{K} 5$, which was $16.71 \% \pm 0.40 \%$. The rice analogue with the lowest hydrolysis index and predicted glycemic index obtained this treatment were $32.14 \pm 0.20$ and $56.79 \pm 0.14$ respectively (Table 2 ). The results showed that the higher amount of modified arrowroot starch added produced higher levels of the resistant starch in rice analogue. However, there was a positive correlation between the resistant starch content enhancement, to the decreasing degree of hydrolysis (HI) and predicted glycemic index (PGI). According to Figure 3, the rice analogue with the lowest total hydrolyzed starch was found in treatment $\mathrm{K} 5$, which was $7.80 \%$ at $30 \mathrm{~min}$ and $14.23 \%$ at $180 \mathrm{~min}$.

Table 2. The Resistant Starch (RS), Hydrolysis Index (HI), and Predicted Glycemic Index (PGI) of Rice Analogue

\begin{tabular}{|c|c|c|c|}
\hline F Treatment & $\begin{array}{l}\text { RS level } \\
(\%)\end{array}$ & $\begin{array}{l}\text { Hydrolysis } \\
\text { Index (HI) }\end{array}$ & $\begin{array}{l}\text { Predicted } \\
\text { Glycemic } \\
\text { Index (PGI) }\end{array}$ \\
\hline K0 (Control) & $\begin{array}{l}3.92 \pm \\
0.31 \mathrm{a}\end{array}$ & $66.15 \pm 0.12 f$ & $\begin{array}{l}76.03 \pm \\
0.32 f\end{array}$ \\
\hline $\begin{array}{l}\text { K1 (NAS } 100 \% \text {, } \\
\text { MAS } 0 \% \text { ) }\end{array}$ & $\begin{array}{l}5.81 \pm \\
0.23 b\end{array}$ & $65.68 \pm 0.17 e$ & $\begin{array}{l}75.77 \pm \\
0.19 \mathrm{e}\end{array}$ \\
\hline $\begin{array}{l}\text { K2 (NAS } 75 \% \text {, } \\
\text { MAS } 25 \% \text { ) }\end{array}$ & $\begin{array}{l}8.36 \pm \\
0.35 c\end{array}$ & $44.79 \pm 0.23 \mathrm{~d}$ & $\begin{array}{l}64.30 \pm \\
0.24 d\end{array}$ \\
\hline $\begin{array}{l}\text { K3 (NAS } 50 \% \text {, } \\
\text { MAS } 50 \% \text { ) }\end{array}$ & $\begin{array}{l}11.22 \pm \\
0.27 \mathrm{~d}\end{array}$ & $40.81 \pm 0.20 c$ & $\begin{array}{l}62.11 \pm \\
0.20 \mathrm{c}\end{array}$ \\
\hline $\begin{array}{l}\text { K4 (NAS } 25 \% \text {, } \\
\text { MAS } 75 \% \text { ) }\end{array}$ & $\begin{array}{l}14.21 \pm \\
0.24 \mathrm{e}\end{array}$ & $35.37 \pm 0.19 b$ & $\begin{array}{l}59.13 \pm \\
0.22 b\end{array}$ \\
\hline $\begin{array}{l}\text { K5 (NAS } 0 \% \text {, MAS } \\
100 \% \text { ) }\end{array}$ & $\begin{array}{l}16.71 \pm \\
0.40 f\end{array}$ & $32.14 \pm 0.20 \mathrm{a}$ & $\begin{array}{l}56.79 \pm \\
0.14 \mathrm{a}\end{array}$ \\
\hline
\end{tabular}

Note: Number followed by the same letter is not significantly different according to Duncan's Test $\alpha=5 \%$,

This is due to the differences in granule size and the levels of resistant starch in the rice analogue. In addition, Dundar and Gocmen (2013) stated that the increased level of the resistant starch was caused by modification through gelatinization-retrogradation method. The results obtained were similar to those of Ratnaningsih et al. (2017), the ability of enzymes to hydrolyze starch was strongly influenced by amylose content, resistant starch content and granule size. In accordance with Damat et al. (2008) and Damat et al. (2020), food products with high contents of resistant starch (RS) had a hypoglycemic effect as well as a low glycemic index. Resistant starch included to food fiber.

Supparmaniam et al. (2019) described that increasing levels of food fiber from starch were able to reduce the glycemic index of the product. In addition-resistant starch, ratio of amylose-amylopectin, the interaction between starch, and other components contained in the product also influenced the glycemic index (Bakar et al., 2019). Moreover, starchy foods with low glycemic index are very good for diabetic and hypertriglyceridemia patients. Ratnaningsih et al. (2017) reported that functional such food products provide a longer feeling of satiety and increase the fermentation process in the colon.

In vitro, analogue rice starch hydrolysis was presented in Figure 3. The analogue rice starch hydrolysis speed and bread as a control increased with time. Analogue rice produced from modified arrowroot starch (MAS) had a lower starch hydrolysis speed than plain bread and natural arrowroot starch at all observation times. Analogue rice made from $100 \%$ MAS has the lowest hydrolysis rate. The analogue rice starch hydrolysis speed was similar to raw green bean starch (Kaur et al., 2015), but it was lower than that reported by Ambaigapalan et al. (2014) on black bean, and pinto bean starch, also on field pea starch (Liu et al., 2015). The analogue rice digestibility of modified arrowroot starch was influenced by the absence of pores on the starch granule surface and the strong interaction between amylose chains due to the gelatinizationretrogradation process. The low digestibility of analogue rice starch was considered related to high amylose content and starch granule size (Hoover et al., 2010; Liu et al., 2015). 


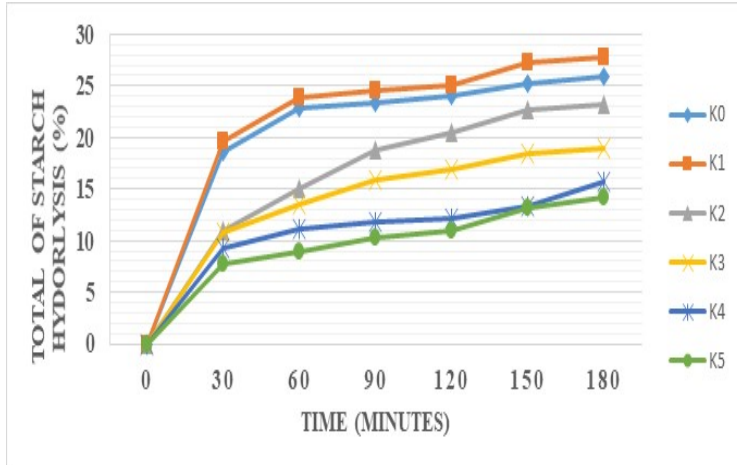

Figure 3. Starch hydrolysis pattern

\section{Conclusion}

The modified arrowroot starch's proportion had a significant effect on the microscopy and digestibility of rice analogue. The modified arrowroot starch enhancement resulted in larger granule size and resistant starch (RS) of rice analogue produced. Moreover, the increasing levels of RS and digestibility, the hydrolysis index (HI), and predicted glycemic index (PGI) of the rice analogue decreased, and rice analogue with low PGI is recommended for healthy diabetics.

\section{Acknowledgements}

The authors wish to thank the Ministry of Research and Technology, Republic of Indonesia, for funding for this research (E.5c/092/DPPM/L/IV/2019).

\section{References}

Abba H, Ibrahim A, Shalllangwa GA, Uba S and Dallatu YA 2014. Effect of acetylation on stability to retrogradation of starch extracted from wild polynesian arrowroot (Tacca leontopetaloides (L.) Kuntze) for utilization as adhesive on paper. J. Polym. 732174:1-9.

Al-Jamal A, and Alqadi T. 2011. Effects of rosemary (Rosmarinus officinalis) on lipid profile of diabetic rats. Jordan J Biol Sci 4(4): 199-204.

Ambigaipalan P, Hoover R, Donner E, and Liu Q. 2014. Starch chain interactions within the amorphous and crystalline domains of pulse starches during heat-moisture treatment at different temperatures and their impact on physicochemical properties. Food Chem. 143:175-184.

Astuti RM, Widaningrum, Asiah N, Setyowati A and Fitriawati R. 2018. Effect of physical modification on granule morphology, pasting behavior, and functional properties of arrowroot (Marantha arundinacea L) starch. Food Hydrocoll, 81:23-30.

Bakar NAFA, Rashid AAA, Ishak MF and Jalil AMM. 2019. Glycemic index of starch-based foods commonly consumed in Terengganu, Malaysia. Malays Appl Biol, 48(4):129-138.

Bhaskar VH and Ajay SS. 2009. Antihyperglycemic and antihyperlipidaemic activities of root extracts of Calotropis procera (Ait.) $\mathrm{R} . \mathrm{Br}$ on streptozotocin induced diabetic rats. Jordan J Biol Sci . 2(4): 177-180.

Budijanto S and Yuliana ND. 2015. Development of rice analog as a food diversification vehicle in Indonesia. J. Sustain. Agric. 10: $7-14$.
Charles AL, Cato K, Huang T, Chang Y, Ciou J, Chang J and Lin H. 2016. Functional properties of arrowroot starch in cassava and sweet potato composite starches. Food Hydrocoll. 53:187-191.

Damat D, Marsono Y, Haryadi and Cahyanto MN. 2008. Hypocholesterolemic and hypoglicemic effects of butyrylated arrowroot starch on Sprague Dawley rats. Indones. J. Pharm. 19(3):109-116.

Damat D, Tain A, Handjani H and Chasanah U. 2017. Microscopy and organoleptic properties of functional pastries form modified arrowroot starch (Maranta arundinaceae L.). Jurnal Aplikasi Teknologi Pangan, 6(4):161-166.

Damat D, Tain A, Handjani H, Chasanah U and Putri DN. 2018. Modified Starch Technology and it's Benefits for Health. UMM Press, Malang, Indonesia.

Damat D, Anggriani R, Setyobudi RH and Soni P. 2019a. Dietary fiber and antioxidant activity of gluten-free cookies with coffee cherry flour addition. Coffee Sci, 14(4): 493-500.

Damat D, Tain A, Handjani H, Chasanah U and Siskawardani DD. 2019b. Functional cake characteristics of modified arrowroot starch (MAS) with the gelatinization-retrograde method. IOP Conf. Ser.: Mater. Sci. Eng. 532 (012017): 1-6.

Damat D, Setyobudi RH, Soni P, Tain A, Handjani H and Chasanah U. 2020. Modified arrowroot starch and glucomannan for preserving physicochemical properties of sweet bread. Cienc. e Agrotecnologia 44(e014820): 1-9.

Deswina and Priadi D. 2020. Development of arrowroot (Maranta arundinacea L.) as functional food based of local resource. IOP Conf. Series: Earth and Environ. Sci. 439 (012041): 1-11.

Dundar AN and Gocmen D. 2013. Effects of autoclaving temperature and storing time on resistant starch formation and its functional and physicochemical properties. Carbohydr Polym, 97(2):764-771.

Fabbri ADT, Schacht RW and Crosby GA. 2016. Evaluation of resistant starch content of cooked black beans, pinto beans, and chickpeas. NFS Journal. 3: 8-12.

Han W, Jiao H and Fox D. 2018. Scanning electron microscopy. In: Wang R, Wang C, Zhang H, Tao J and Bai X. (Eds.) Progress in Nanoscale Characterization and Manipulation. Springer Tracts in Modern Physics. 272: 35-68. Springer Singapore.

Hoover R, Hughes T, Chung HJ, and Liu Q. 2010. Composition, molecular structure, properties, and modification of pulse starches: A review. Food Res. Int. 43(2): 399-413.

Kaur M, Sandhu KS, Ahlawat R and Sharma S. 2015. In vitro starch digestibility, pasting and textural properties of Mung Bean: Effect of different processing methods. J Food Sci. Technol. 52(3):1642-1648.

Lestari LA, Huriyati E and Marsono Y. 2017. The development of low glycemic index cookie bars from foxtail millet (Setaria italica), arrowroot (Maranta arundinacea) flour, and kidney beans (Phaseolus vulgaris). J. Food Sci. Technol. 54(6):1406-1413.

Lin L, Huang J, Zhao L, Wang J, Wang Z and Wei C. 2015. Effect of granula size on the properties of lotus rhizome C-type starch. Carbohydr. Polym. 134: 448-457.

Liu C, Wang S, Copeland L and Wang S. 2015. Physicochemical properties and in vitro digestibility of starches from field peas grown in China. LWT Food Sci Technol. 64(2):829-836.

Majzoobi M, Kaveh Z and Farahnaky A. 2016. Effect of acetic acid on physical properties of pregelatinized wheat and corn starch gels. Food Chem. 196:720-725. 
Maulani RR, Fardiaz D, Kusnandar F and Sunarti TC. 2013. Characterization of chemical and physical properties of hydroxypropylated and cross-linked arrowroot (Marantha arundinacea) starch. J. Eng. Technol.Sci. 45(3):207-221.

Pepe LS, Moraes J, Albano KM, Telis VRN and Franco CML. 2015. Effect of heat-moisture treatment on the structural, physicochemical, and rheological characteristics of arrowroot starch. Food Sci. Technol. Int. 22(3):256-265.

Ratnaningsih N, Suparmo, Harmayani E and Marsono Y. 2017. In vitro starch digestibility and estimated glycemic index of Indonesian cowpea starch (Vigna unguiculata). Pak. J. Nutr. 16(1):1-8

Setyobudi RH, Zalizar L, Wahono SK, Widodo W, Wahyudi A, Mel M, Prabowo B, Jani Y., Nugroho YA, Liwang T, and Zaebudin A. 2019. Prospect of Fe non-heme on coffee flour made from solid coffee waste: Mini review. IOP Conf. Series: EES. 293(012035):1-24.
Sholichah E, Deswina P, Sarifudin A, Andriansyah CE and Rahman N. 2019. Physicochemical, structural and morphological properties of some arrowroot (Maranta arundinacea) accessions growth in Indonesia. AIP Conf. Proc. 2175(020008):1-9.

Supparmaniam H, Hussin N and Jalil AMM. 2019. Glycaemic index, palatability, acceptability and perceived satiety of cookies prepared with durian (Durio zibethinus Murr.) and $\beta$-glucan. Malays Appl Biol. 48(4):89-99.

Villas-Boas F and Franco CML. 2016. Effect of bacterial $\beta$ amylase and fungal $\alpha$-amylase on the digestibility and structural characteristics of potato and arrowroot starches. Food Hydrocoll. 52: 795-803.

Wahjuningsih SB, Haslina H and Marsono M. 2018. Hypolipidaemic effects of high resistant starch sago and red bean flour- based analog rice on diabetic rats. Mater. Sociomed. 30(4): 232-239. 